Michaël Meysman ${ }^{1}$

\title{
Belgium and the European Arrest Warrant: Is European Criminal Cooperation Under Pressure?
}

\author{
Refusal of European Arrest Warrant Surrender in the Case Jauregui Espina \\ as Proof of Failing Mutual Trust
}

Abstract:

In its judgment of the $19^{\text {th }}$ of November 2013, Belgium's highest court, the Court of Cassation, confirmed an earlier judgment of the so-called kamer van inbeschuldigingstelling (KI) of the Court of Appeal in Ghent in response to a surrender demanded in accordance with a number of European arrest warrants issued by Spain. This surrender was brushed off the table by the KI on the basis of a motivation basedon themutual trust concerning thecompliance with fundamental rights within the context of European cooperation in criminal matters. ${ }^{2}$ This motivation seems bound to raise eyebrows amongst those who advocate this classic tenet of cross-border cooperation. This article frames this recent judgement within a European context, and investigates whether there is indeeda European tendency to step away from blind trust in lieu of (successfully) invoking fundamental rights to refuse cooperation. The case under scrutiny already seems to be pointing in that direction as far as the member states are concerned. Moreover, it seems to be confirmed by recent statements within the European Court of Justice (ECJ) by the Advocates General, as well as through the new procedural wind blowing through the Union with the Procedural Roadmap. On the other hand, the ECJ shows itself more reluctant than expected, giving rise to a situation in which member states

1 The author is a Researcher at the Institute for International Research on Criminal Policy (IRCP) at the Department of Criminology, Criminal Law and Social Law of the Ghent University. His research focuses on the European Criminal Policy and the position of mentally disordered suspects and offenders in European Criminal Law. Corresponding author: Dr. Michaël Meysman, RE023, IRCP, Universiteitstraat 4, 9000 Gent.Michael.Meysman@ugent.be.This Article is an adaptation and update of a previously published contribution to Pantopticon, Tijdschrift voor Strafrecht, Criminologie en Forensisch Welzijnswerk, 2014

2 In the context of mutual recognition, the term 'European cooperation in criminal matters' still primordially intends judicial cooperation, often to the critique of scholars, see, f.i.: G. Vermeulen, Het Stockholm-zwartboekjustitieenpolitie.Een trieste inventaris van Belgische en Europese onverantwoordelijkheid en visieloosheid. Panopticon Tijdschrift voor Strafrecht, Criminologie en Forensisch welzijnswerk(Panopticon), 34 (5), 2013, pp. 349-367.

DOI: $10.5771 / 2193-5505-2016-2-186$ 
and involved individuals remain in the dark with regard to a consistent line on the complex relation between smooth European cooperation in criminal cases and respect for fundamental rights. The Union moreover appears to be increasingly moving away from cooperation in criminal cases - despite the fact that it concerns a competence enshrined in treaty law - in exchange for a harmonisation of national (minimum) standards. A noble motive, which in this case however carries the potential to further complicate, or even undermine, the necessary trust and guarantees for fundamental rights in criminal cases. The recent judgement by the Court of Cassation also demonstrates that the matter of human rights requires an adequate response, not only to permanently ensure and improve the protection of fundamental rights, but also to avoid that more and more spanners are thrown in the works of smooth European cooperation in criminal matters.

Key words: Moreno \& Garcia - Gomez \&Ugarte - Jauregui Espina - mutual recognition- fundamental rights - European Arrest Warrant

\section{Introduction: Déjà vu for the European arrest warrant?}

On the $19^{\text {th }}$ of November 2013, the Belgian Court of Cassation dismissed the appeal against the ruling of the $\mathrm{KI}^{3}$ of the Ghent Court of Appeal ${ }^{4}$, in which the latter had opposed the surrender to the Spain of Maria Natividad - 'Jaione' - Jauregui Espina ${ }^{5}$ on the basis of two ${ }^{6}$ European arrest warrants (EAW). ${ }^{7}$ The Ghent KI had ruled that the surrender to Spain of Jauregui Espina ${ }^{8}$, affiliated to the Basque resistance and separatist

3 Under Belgian law, the KI decides - but only for the most serious offences - at the end of a judicial investigation whether there is enough evidence of guilt against a defendant under criminal investigation. When sufficient evidence is provided the KI will refer the suspect to the highest criminal court (Assisen). In an EAW context, the KI needs to decide on whether sufficient elements are available to decide on its execution. The KI also acts as a court of appeal against decisions by the Raadkamer (see infra).

4 Hof van Cassatie, 19 november 2013, AR P.13.1765.N, via: http://jure.juridat.just.fgov.be/pdf app/download_blob?idpdf=N-20131119-5.

5 This article wishes, by all means, to refrain from detracting the privacy and anonimity of the persons involved. But in light of previous coverage of the case in the weekly periodical 'knack' (dossier Knack, 23 October 2013) and Ms. Jauregui Espina's own contribution - under the pseudonym 'Jaione' - to a relatively well known and popular cooking book (Eenvreemd Gents kookboek, uitgeverijLannoo), it seemed appropriate to refer to the person involved by name and surname.

6 The EAW's were issued on 9th July, 2004 and 1st December, 2005 respectively.

7 The European Arrest Warrant was introduced with the Council Framework Decision of 13 June 2002 on the European arrest warrant and the surrender procedures between Member States (2002/584/JHA). Available via: http://eur-lex.europa.eu/legal-content/EN/TXT/ $\mathrm{HTML} /$ ?uri=CELEX:32002F0584\&from=EN.

8 Jauregui Espina was linked in both European Arrest Warrants to the Bask ETA and was suspected of attempted murder and terrorism (EAW of 2004), participation to a criminal organisation, terrorism, manslaughter, aggravated assault and murder (EAW of 2005). These accusations were based on her - putative - involvement in facts that occurred in Bilbao on the 14th of June and 19th of January 1981.

EuCLR Vol. 6, 2/2016 
movement ETA 9 , would entail a risk of fundamental rights infringement as guaranteed in article six of the Treaty on the European Union. ${ }^{10}$ The federal prosecutor had appealed against this ruling pleading the insufficient justification by the KI of its decision, as well as a violation of Article 4, $5^{\circ}$ of Belgium's Law on the European Arrest Warrant ("Wet EAB") ${ }^{11}$ but, as mentioned, to little avail before the high Court.The narrative and content of this case will undoubtedly instil an unpleasant feeling of déjà $v u$ in both the Belgian and Spanish (judicial) authorities. The setting - a procedure that concerns the surrender on the basis of a European arrest warrant - as well as involved actors - the KI, federal prosecutor, Court of Cassation - and context - a Spanish Basque affiliated to ETA and suspected of (involvement in) serious crimes - are all heavily reminiscent of the Moreno-Garcia case. The same is also true for the result of the procedure, in which the KI (this time to the Court of Appeal of Antwerp) in its ruling on the $23^{\text {rd }}$ of June 2004 opposed the surrender of this Spanish - Basque couple. Notwithstanding these similarities, the Jauregui Espina case should not be examined through the exact same lens given that, rather than old wine in a new bottle, it concerns a substantially different approach by the Belgian judicial authorities to the issue of surrender on the basis of a European arrest warrant. While this is in part due to a differing judicial context and the then inexperience in 2004 of the Belgian authorities with the new European instrument, it also indicates a mentality change currently taking place in the field of European cooperation on criminal cases. The period following the spate of terrorist threats and attacks that marked the first years of the new Millennium were characterized by an approach that was heavily focused on prosecution, which resulted in a wide range of instruments geared towards tracking, prosecuting and punishing crimes with a cross-border dimension. Within this context, the European arrest warrant not only constitutes the first effective mutual recognition instrument to be created, to date it is also the most successful. ${ }^{12}$ In more recent years, however, it appears a profound change has come about in which stronger focus is placed on

9 ETA (Euskadi ta Askatasuna)is an armed Basque nationalist and separatist organization in northern Spain (and southwestern France). It grew during Franco's dictatorship and was officially founded in 1959. Originally aimed at promoting traditional Basque culture, it evolved into a paramilitary group.Through the years, it held a violent campaign of bombing, assassinations and kidnappings in the Spanish Basque country and throughout Spanish territory. Its goal was gaining independence for the Greater Basque Country. In 2011 ETA announced a definitive cessation of its armed activities and in 2012, the BBC reported that it was ready to negotiate a definitive end of its operations.

10 Consolidated Version of the Treaty on the European Union (TEU),OJ 2012 C 326/01. Via:http://eur-lex.europa.eu/legal-content/EN/TXT/HTML/?uri=CELEX:12012M/

TXT\&from $=$ en.

11 Wet van 19 December 2003 betreffende het Europees Aanhoudingsbevel. Via: http://www.ej ustice.just.fgov.be/cgi_loi/change_lg.pl?language $=$ nl\&la $=$ N\&cn=2003121932\&table_name= wet.

12 B. Thellier de Poncheville, La confiancemutuelle à l'épreuve du mandatd'arrêtEuropéen, in: D. Zerouki-Cottin (Ed.), L'espacePénalEuropéen: À la croisée des chemins? Actes de la journéed'études du 30 mai 2013, Université Jean Monnet Saint-Étienne, France: La Charte, 2013, pp. 29-40. 
procedural guarantees in a wider framework of conformity with fundamental rights. This evolution will be illustrated below on the basis of a comparison between three similar cases and with the recent ruling of the Ghent KI and its confirmation by the Court of Cassation as terminus. Subsequently, this article will examine whether European criminal law is indeed witnessing a 'revival of fundamental rights' and, if this were to be the case, what role can be attributed to the Jauregui Espina ruling in this context.

II.Travelling back in time. The case Moreno-Garcia as a first big test for the European arrest warrant and the Belgian judicial system ${ }^{13}$

Hardly a month following the entry into force on 30th January, 2004 of the scantily adopted "Wet EAB"14, Belgium found itself confronted with a European arrest warrant issued by Spain regarding the Moreno-Garcia couple. The duo, which was of Spanish-Basque origin but had acquired Belgian nationality in 2001, was suspected of participation in ETA terrorist acts, forming part of an armed gang and unlawful assembly. It would not take long before the further course of the proceedings concerning arrest and surrender would turn into a test case ${ }^{15}$ for the European arrest warrant. This was due to the fact that, immediately following its issuing, the arrest warrant kicked off a procedural Calvary which saw the couple appear four times before the $\mathrm{KI}^{16}$ and three times before the Court of Cassation before the KI of Antwerp finally rejected their surrender to Spain. The Belgian nationality, which was acquired by the couple through the established procedures, turned out to be the main cause for the procedural battle that quickly transformed into an entrenched episode of legal-technical warfare concerning the jurisdiction and competence of the Belgian judicial authorities to deal with the Spanish indictments by means of an EAW themselves. ${ }^{17}$ Both relevant and re-

13 This contribution only refers in a limited degree - when considered relevant - to the extensive EAW-procedure in the Moreno-Garcia case. For a comprehensiveoverview, see:C. Ryngaert, Het Europees aanhoudingsbevel lastens Moreno-Garcia: de aanhouder wint, Nieuw Juridisch Weekblad (NJW), 2004, pp. 1226-1233.

14 The Belgian "Wet EAB" was only adopted by the Belgian Senate at the eleventh hour. In accordance with Article 34 (1) of the EAW Framework Decision, the Member States were due to take all necessary measures by 31 December 2003 at the latest to comply with the Decision's implementation in National law and in accordance with its provisions. Since the first of January 2004, the Belgian Wet EAB is applicable for the arrest and surrender of a person sought on the basis of an EAW.

15 L. Janssens, De zaak Moreno-Garcia, een testcase voor het Europees aanhoudingsbevel, Noot onder Cass. 13 april 2004, Cass. 11 mei 2004 en Cass. 8 juni 2004, Rechtskundig Weekblad(R.W.), 2004-05, 2004, pp. 1260-1262.

16 Three appearances before the Brussels KI and one (last) appearance before the Antwerp KI.

17 Describing the Moreno-Garcia case as a judicial ordeal is an understatement and doesn't do it justice: Even before the procedural battle concerning the EAW-Based surrender the couple, - then still under Spanish Nationality - was the subject of a complex legal imbroglio and the target of judicial authorities flexing their muscles, both between the Belgian internal authorities and between Spain and Belgium. For anextensive and enlightened analysis of thislegalquagmire, see:G. Vermeulen \& T. Vander Beken, Uitlevering Basken aan Spanje: Juridische bedenkingen bij een politieke zaak, Recente Arresten van de Raad van State, 1995, pp. 221-232. 
markable is the minimal importance that was accorded to the human rights dimension in the course of all these proceedings.

The Moreno-Garcia defence did argue, on the basis of a report concerning Spain authored by the (then) Special Rapporteur of the UN Commission for Human Rights ${ }^{18}$, that a surrender in accordance with the European arrest warrant risked to entail an infringement of their fundamental rights, but this line of defence fell on deaf ears. This dismissal was significant, however, given that the Belgian legislator - going against the spirit of the mutual trust tenet - had in fact included such mandatory grounds for refusal in article $4,5^{\circ}$ of its "Wet EAB". ${ }^{19}$ As such, interestingly enough, the execution of the Arrest Warrant never - at least formally - came under pressure because of the applied prosecutorial techniques and specific detention conditions for ETA-suspects in Spain. Rather than focusing hereupon, the parties involved dedicated the entire procedure to fixating on the techno-legal conundrums concerning the application of the other refusal ground, foreseen in Article 4, $4^{\circ}$ of the Wet "EAB" 20 , whereby the Belgian Nationality of Moreno-Garcia would prevent surrendering to Spain. With hindsight, it seems fair to state that this approach reflects the European momentum that characterized the beginning of the new Millennium, given that the principle of mutual recognition in criminal cases ${ }^{21}$ opposed a line of reasoning in which the executing Member State would refuse the execution - recognition - of a judicial decision due to a lack of confidence vis $a$ vis the established practices and procedures of the issuing Member State.

The basic notion that the members of the Union would be able to blindly ${ }^{22}$ confide in each other's efficiency and justness on the basis of their democratic nature and their allegiance to European and International (Human Rights) conventions and treaties,

18 Th. Van Boven, Report of the Special Rapporteur on the question of torture, 2004. Via: http://www.apt.ch/content/files/Spain_SRT\%20Report\%20Feb\%202004.pdf.

19 Article $4,5^{\circ}$ of the "Wet EAB" provides a (mandatory) refusal ground when there are substantial reasons to believe that the execution of an EAW would infringe the fundamental rights of the persons involved as guaranteed by Article 6 of the Treaty on the Functioning of the European Union.

20 Article 4, $4^{\circ}$ "Wet EAB" establishes that the execution of an EAW is refused in case $\left(4^{\circ}\right)$ the prosecution or punishment is barred under Belgian law and the Belgian courts have jurisdiction to take cognisance of the facts for which the EAW was issued. The conditions under this article need to be met cumulatively. With regards to the jurisdiction of the Belgian courts, Articles 6 and 7 of the Belgian "Wetboek van Strafvordering" (Penal Procedure Code) state that a person with the Belgian Nationality or with principal residence in Belgium can only be sentenced under Belgian law under certain conditions and limited to specific offences. Incidentally, these articles are the consequence of the debacle with the Belgian Genocide Law of 1993, formally abolished with the Belgian Law of 5 August 2003.

21 For a concise overview of the mutual recognition principle, see: H.G. Nilsson, From classical judicial cooperation to mutual recognition. Revue internationale de droit pénal, $77(2006 / 1)$, 2006, pp. 53-58.

22 H. Labayle, Mandatd'arrêteuropéen et degré de protection des droits fondamentaux, quand la confiance se fait aveugle. Groupe de Recherche - EspaceLibertéSécurité Justice, 2013. Via: http://www.gdr-elsj.eu/2013/03/03/cooperation-judiciaire-penale/mandat-darret-europeenet-degre-de-protection-des-droits-fondamentaux-quand-la-confiance-se-fait-aveugle/print/. 
constituted the linchpin of this discourse that had to render a swift and efficient cooperation in criminal cases where possible. The hotly debated ${ }^{23}$ absence of (explicit) grounds for refusalbased on the compliance withFundamental Rights and Freedomsin the Framework Decision - be they mandatory or optional - constituted one of the main stalking horses in the stable of mutual trust. This can, however, by no means be understood in the sense of the Framework Decision clearing the path for a technique of surrender that is devoid of any type of control concerning the respect of fundamental rights. ${ }^{24}$ As stated before, Member States moreover have been far from silent as far as the introduction of grounds for refusal was concerned. ${ }^{25} \mathrm{As}$ a result hereof, the Moreno-Garcia case occupies an important position in this context seeing that an EAW that was issued on the basis of terror-related crimes seemed a textbook example of the wind of change blowing in the field of European criminal law. This first major test for the principle of mutual recognition and its flag ship, the European arrest warrant, clearly constituted a false start. Rather than leading to the smooth cooperation hoped for, the Warrant became entrenched in a legal standoff between Belgium's sitting (bluntly put: judges, traditionally more poised to balance the pros and cons of a legal measure) and standing magistrates (the state prosecution, traditionally aiming at fasttrack prosecution and smooth cross-border cooperation) with the Court of Cassation in the role of headsman. The principle of mutual trust nevertheless survived this first test, seeing that the Belgian judiciary did not have to take recourse to an own-initiative ground for refusal concerning the guarantees for fundamental rights.

\section{The Gomez \& Ugarte case. The limited scope of the human rights argument?}

It is worthwhile to briefly pay attention to the similar (and almost simultaneously occurring) case of the duo Jon Lopez Gomez and Diego Ugarte Lopez de Arkaute. This time, the Belgian judiciary did find itself obliged to pronounce itself on the possible infringement of fundamental rights, seeing that the involved actors were not in a position to appeal on any other grounds for refusal. Once again, the case concerned two Basque members of ETA, who were arrested by Belgian police driving a stolen car with false license plates. Both were the subject of a European arrest warrant issued by Spain, and once more the above-mentioned Spain-report published by the Special Rapporteur of the UN was invoked by the defence. The main difference with the Moreno-

23 S. Alegre E M. Leaf, Mutual recognition in European judicial cooperation: A step too far too soon? Case study - the European arrest warrant, European Law Journal (ELJ), 10(02), 2004, pp. 200-217; S. Dewulf, Handboek uitleveringsrecht. Intersentia, 2013, p. 244.

24 Article 1,3. Of the EAW Framework Decision clearly stipulates that "This framework Decision shall not have the effect of modifying the obligation to respect fundamental rights and fundamental legal principles as enshrined in Article 6 of the Treaty on the European Union”.

25 European Commission, Report from the Commission based on Article 34 of the Council Framework Decision of 13 June 2002 on the European arrest warrant and the surrender procedures between Member States (revised version) $\{$ SEC(2006)79\} $/ *$ COM/2006/0008 final $\%$ 2006, p. 8.Via: http://eur-lex.europa.eu/LexUriServ/LexUriServ.do?uri=COM: 2006:0008:FIN:EN:HTML. 
Garcia case resided in the fact that, this time, the "KI" (in Mons this time) did find itself obliged to pronounce itself on this argument, but finally decided that the report referred to only carried "a limited and general value and moreover was not sufficiently endorsed and supported by the UN Human Rights Commission". ${ }^{26}$ The KI therefore had to ascertain itself of the potential negative consequences of surrendering the involved actors to Spain (and therefore also to indicate - at least implicitly - a possible lack of trust concerning the criminal proceedings as well as the material detention conditions in Spain). It finally decided, however, that there were no sufficient reasons to justify the assumption that the implementation of the European arrest warrant would infringe upon the fundamental rights of the accused. Moreover, this decision was not revoked by Belgium's highest ranking court. ${ }^{27} \mathrm{Also}$ in this case, the KI found the principle of mutual recognition to carry the strength needed to trump the special report of the UN Human Rights Commission and brush any reasonable doubt concerning the presupposed trust in the Spanish system off the table. The final conclusion therefore read that there was insufficient indication that Spain was violating fundamental human rights, which would entail an obligation to refuse the surrender conform art. $4,5^{\circ}$ "Wet EAB".

\section{A closer look at the Jauregui Espina case}

Fast forward to 2013. Eight, nearly nine years after the warrants have been issued by the Spanish authorities, Jauregui Espina is arrested by the police and taken into custody on $9^{\text {th }}$ October in Ghent upon decision (order) of the investigative judge. The "Raadkamer" 28 of Ghent decided on $16^{\text {th }}$ October that the European arrest warrants could be executed. Following appeal against this decision, the KI of Ghent subsequently amended the decision and worked and dismissed its execution. ${ }^{29}$ Taking a closer look at the context, it is notable that, as far as the factual events are concerned, the case is located somewhere between the cases Moreno-Garcia and Gomez-Ugarte: While Moreno-Garcia had already acquired the Belgian nationality at the time when

26 Kamer van Inbeschuldigingstelling, Hof van Beroep Bergen, 13 mei 2004,not published; G. Stessens, Het Europees aanhoudingsbevel. De wet van 19 december 2003, CBR Jaarboek 2004-005, Maklu, Antwerpen-Apeldoorn, 2005, p. 38.

27 Hof van Cassatie, 26 mei 2004, AR P.04.0779.F, via: http://jure.juridat.just.fgov.be/pdfapp/d ownload_blob?idpdf=F-20040526-11.

28 The Raadkamer, like the KI, decides at the end of a judicial investigation whether there is enough evidence of guilt against a defendant under criminal investigation. When sufficient evidence, is provided, the Raadkamer will summon the suspect before the correctional criminal court. If this would not be the case, the suspect is dropped from further prosecution. Likewise, in an EAW context, the Raadkamer needs to decide on whether sufficient elements are available to decide on its execution. Its relation to the KI is that the latter acts as a court of appeal for decisions of the Raadkamer. Apart from this, the KI has the exclusive competence to decide on the referral of a suspect to the highest criminal court (of Assisen) for the most serious offences.

29 Kamer van Inbeschuldigingstelling, Hof van Beroep Gent, 31 oktober 2013, KI 2013/FP/16. 
the EAW was issued (a situation that kicked off a technical debate on conditions concerning nationality and residence that would allow for prosecution by the Belgian judiciary on the basis of art 4,4 $4^{\circ}$ Law EAW), and while Gomez-Ugarte were merely passing through Belgium and were not in a position to claim any connections to the country when they were arrested by the police in Boussu, which left Art. $4,5^{\circ}$ of the Law EAW as the only possible option, Jauregui Espina resided for years on end in Ghent, without, however, having acquired official residence.It is, therefore, all the more remarkable that this is precisely where Jauregui Espina's defence vested its main hope. In its appeal against the Raadkamer's decision, the defence stated first and foremost that the implementation of both EAWs had to be dismissed due the facts being barred by Belgian law and the competence of the Belgian courts to ascertain themselves of the facts, an assertion based once again on a combined reading of Art. $4.4^{\circ}$ Law EAW and the stipulations of Belgium's penal procedure code (Articles $6 \& 7$ ) on the basis of which a Belgian citizen or a person holding principal residence in Belgium (under certain conditions and for certain crimes) has to be convicted in Belgium). ${ }^{30} \mathrm{Al}-$ though identical to the procedure in the Moreno-Garcia case, here this made little sense as far as Jauregui Espina was concerned given her precarious situation of residence, rendering this line of defence exceptionally weak. ${ }^{31}$ It therefore hardly comes as a surprise that the KI did not accord an enormous amount of attention to this primary objection in its judgement. It was only in the second instance that the human rights discourse was raised as grounds for refusal, given the presumed existence of significant indications in accordance with Art. $4,5^{\circ}$ of the "Wet EAB" to the effect that a surrender to Spain could entail a risk to a violation of the fundamental rights.

The main piece of evidence that was brought forward in support of this assertion was a report by the European Committee for the Prevention of Torture and Inhuman Treatment or Punishment (CPT) of the Council of Europe. ${ }^{32}$ This country-specific report also studied the separate procedures and detention conditions of persons who were suspected of maintaining relations with ETA. ${ }^{33}$ However, while the human rights

30 The facts for which she had been charged stemmed from 1981.

31 The KI, in its decision, refers to the statements regarding her residence situation as follows: appellant claims to reside in -Ghent but refuses to specify where. Furthermore, appellant is currently not registered in Belgium and was in fact never registered in Belgium. Similarly, for the address where she was found, no official person was ever registered. The appellant is by no means familiar to the public department services and the migration services. And she was never signed in at these migration services of Ghent. The apartment was rented by someone else.

32 European Committee for the Prevention of Torture and Inbuman Treatment or Punishment (CPT), Report to the Spanish government on the visit to Spain carried out by the European committee for the prevention of torture and inhuman or degrading treatment or punishment (CPT) from 31 May to 13 June 2011, 2013. via: http://www.cpt.coe.int/documents/esp/ 2013-06-inf-eng.pdf.

33 The so-called "Incommunicado detention" in which the persons involved are placed in quasi-isolated detention conditions and interrogated. Both in terms of theme and scope, this is well-nigh identical to the Van Boven report(fn. 18) in the cases Moreno-Garcia \& GomezUgarte.

EuCLR Vol. 6, 2/2016 
argument had played no role whatsoever in the Moreno-Garcia case, and while similar reports in the Gomez-Ugarte case had been deemed insufficient to conclude towards the existence of substantial reasons to fear for an infringement of fundamental rights, the $\mathrm{KI}$ in this case referred specifically to the CPT report in support of its refusal to execute the mandates for arrest. This notwithstanding the striking similarity between both concerned reports in terms of both scope and contents. As was the case for Moreno-Garcia, we can once again refer to the clearly distinct points of view of the sitting and standing magistrates in the present context: By mentioning the assumption that the issuing state acts in respect of human rights as well as Spain's ratification of the European Convention on Human Rights and Fundamental Freedoms, the Federal Prosecutor (standing) endorsed the classical philosophy of mutual recognition in his interpretation of Article 4,5 "Wet EAB". ${ }^{34}$ It was amply stated that Spain enjoys a democratic tradition. With the apparent trust in the Spanish judicial system forming the point of departure, the facts subsequently raised through the CPT report were then checked against the stipulations of the "Wet EAB" with the Prosecutor finally concluding that the "Wet EAB" only refers to substantial reasons, which means a flagrant violation of human rights had to be in play. The facts raised on the basis of reference to general reports by international organisations did not meet this criterion according to the prosecutor, given they did not include (a sufficient number of) concrete elements in order to conclude towards an infringement of the fundamental rights.

It appeared that the Prosecutor's point of view in this was supported by the Court of Cassation. Indeed, the Court traditionally argued in the same vein that, only when in a concrete case, it appeared from ample facts that there was a risk of flagrant violation of one or multiple fundamental rights, recourse could be taken to this ground for refusal. ${ }^{35}$ Moreover, the legacy of the case Gomez-Ugarte becomes apparent when the prosecutor states that a (non-binding) report by an international organisation is insufficient to conclude towards a justified fear for a violation of human rights. It became apparent, however, that the KI of Ghent was not an adept of the above mentioned classical line. On the contrary, it did not question the value of the CPT report, but ruled that the arraignment included in the report concerning the inhuman treatment as a result of specific regimes for ETA suspects did constitute a sufficiently substantial reason to conclude towards a potential infringement of the fundamental rights in case of execution of the EAWs. The KI then argued that the Raadkamer of Ghent and the prosecutor had wrongly presupposed Spain's compliance of the fundamental rights and boldly stated in support of this that "first and foremost there never is an assumption of respect for human rights". In addition to this, the KI raises the "Wet EAB" itself, given that the latter "contradicts the existence of an assumption of respect for human rights

34 Even though the federal prosecutor's claim made the mistake of referring to Article $4,4^{\circ}$ and citing it as $4,5^{\circ}$ "Wet EAB".

35 Dewulf (fn. 23), p. 249. The Court of Cassation did not make this up out of thin air, but based itself on the benchmarks of the European Court of Human Rights that, ever since the Soering case, consistently applies the 'flagrant' character of a denial of infringement of fundamental rights as a threshold. 
seeing that the law itself provides for the possibility to demonstrate or point out the possible existence of substantial reasons to fear for a violation of human rights and therefore also for an (obligatory) refusal of implementation of the EAW".

The KI finally also reacted to the benchmark raised by the prosecutor to the effect that a flagrant violation had to be in play, by stating that the "Wet EAB" did not anywhere in its provisions demanded proof of a state of absolute certainty that there had been or would be a violation of fundamental rights. It is clear that the KI resolutely dismisses the reasoning followed by the federal prosecutor across the line. By plainly stating there can never be a presupposition of respect for human rights, the KI moreover appears to do away with the philosophy of mutual recognition with the single stroke of a pen. Nine years after Moreno Garcia, the confirmation of this decision by the Court of Cassation appears to lend power to the notion that the principle of mutual trust between the European Union's member states has reached its date of expiry.

\section{Causal connection to a European trend?}

One could ask whether the ruling of the KI in the Jauregui Espina case and the confirmation by the Court of Cassation can be framed within a broader European trend. Over the course of the past years, it appears the focus has moved from swift prosecution to a European cooperation in criminal cases in which (more) attention is given to fundamental and procedural rights. It appears that the cause for this change in attitude is the realization that the envisioned and presupposed mutual cooperation between member states based on mutual trust is not working as smoothly as initially hoped. Since it was confirmed as the cornerstone of cooperation in criminal cases during the European Council in Tampere ${ }^{36}$ the concept of mutual recognition has encountered its fair share of obstacles and controversy. The presupposed trust between member states - and therefore the willingness to efficiently recognise and cooperate - turned out less steadfast than expected. In the past, there were the constitutional issues related to the principle instrument of the EAW ${ }^{37}$ and the aforementioned tendency of member states to include grounds for refusal on their own initiative. Today, it appears that the delayed implementation and transposition of European framework decisions into national $\mathrm{law}^{38}$ as well as the significant differences that exist between member states regarding this implementation ${ }^{39}$, constitute the main obstacles to an efficient form of

36 European Council, Tampere European Council Presidency Conclusions, 1999. Via: http://w ww.consilium.europa.eu/uedocs/cms_data/docs/pressdata/en/ec/00200-r1.en9.htm.

37 Alegre E Leaf, ELJ 2004. With many of the member states' constitutional courts objecting the surrender of own nationals under the EAW, opposed certain procedural aspects of the EAW-procedures and, indeed, the individual rights of the persons involved.

38 Vermeulen, Panopticon2013. In this respect, it should be pointed out that Belgium serves as one of the bad pupils in the European class. In the period of 2012-2013, Belgium implemented four framework decisions in national legislation with delays (and belated deadlines) ranging from six months to over five years.

39 A. Suominen, Different implementations of mutual recognition framework decisions. eucrim(1/2011), 2011, pp.24-27. 
mutual recognition. Until recently, the EAW was the sole instrument which, after a false start, seemed able to weather the storm that raged in this field. Before long, however, the EAW fell victim to its own success, with the excessive and disproportional use that was made of the instrument giving rise to criticism from practitioners ${ }^{40}$ and academics ${ }^{41}$ alike. Beyond the hesitant attitude of the member states, however, this progressive trends appears to have its roots in a more substantial issue.

The quintessence of the legitimation for the mutual recognition and cooperation between the member states was based on the supposition that all of them endorsed a mutual commitment to the principles of freedom, democracy, and respect for human rights, fundamental freedoms and the rule of law. ${ }^{42}$ The collective membership of the member states to the European Convention on Human Rights constituted the main supporting argument in this respect. ${ }^{43}$ This legitimisation, however, was dealt a couple of hard blows over the ensuing years. First of all, the jurisprudence of the European Court time and again raises persistent problems with regard to human rights in the member states. As such, the statement that "Furthermore, the Convention, as interpreted by the European Court of Human Rights, is an important foundation for Member States to have trust in each other's criminal justice systems and to strengthen such trust" ${ }^{\prime 4}$ seems to be backfiring on the European institutions and the member states. Re-

40 European Commission, Report from the Commission to the European Parliament and the Council on the implementation since 2007 of the Council Framework Decision of 13 June 2002 on the European arrest warrant and the surrender procedures between Member States Brussels: 11.4.2011,COM/2011/175 Final, via:

http://ec.europa.eu/justice/criminal/files/eaw_implementation_report_2011_en.pdf. In this report, the Commission already indicated the necessity - as identified by the member states for a proportionality test to provide an answer for the excessive amount of EAW's being issued in Europe.

41 S. Haggenmüller, The Principle of proportionality and the European arrest warrant. Oñati Socio-legal Series [online], 3 (1), 2013, pp. 95-106. via: http://papers.ssrn.com/sol3/ papers.cfm?abstract_id $=2200874$

42 Council of the European Union.(2001). Programme of measures to implement the principle of mutual recognition of judicial decisions in criminal matters.OJ C12/10, via: http://eurlex.europa.eu/LexUriServ/LexUriServ.do?uri=OJ:C:2001:012:0010:0010:EN:PDF.The implementation programme clearly states: "That trust is grounded, in particular, on their shared commitment to the principles of freedom, democracy and respect for human rights, fundamental freedoms and the rule of law."

43 C. Van den Wyngaert, Strafrecht, strafprocesrecht \& internationaal strafrecht, Deel II: Strafprocesrecht \& internationaal strafrecht, Antwerpen-Apeldoorn, Maklu, 2003, p. 1145 et seq.

44 Consideration (2) of the Procedural Roadmap: Council of the European Union. (2009). Resolution of 30 November 2009 on a Roadmap for strengthening procedural rights of suspected or accused persons in criminal proceedings.OJ C 295/1, via: http://eur-lex.europa.eu/ LexUriServ/LexUriServ.do?uri=OJ:C:2009:295:0001:0003:EN:PDF. 
cent (2014 \& 2015) convictions of both Belgium ${ }^{45}$ and Spain ${ }^{46}$ before the Human Rights Court with regard to their detention conditions may serve as concrete and relevant examples in this respect. Mutual trust therefore seems to give rise to scenarios of the pot calling the kettle black. Such confrontational human rights jurisprudence appears to undermine, rather than strengthen, the notion that this would contribute to a strengthening of mutual trust. And the member states are not alone in being sensitive to this boomerang effect. The European Union's institutions seem to be waltzing to the same tune.

In the well-known Radu judgment by the Court of Justice that was issued following a prejudicial question related to the implementation of EAW s ${ }^{47}$ it was stated unambiguously in the conclusion by Advocate General Sharpston that "While the record of the Member States in complying with their human rights obligations may be commendable, it is also not pristine. There can be no assumption that, simply because the transfer of the requested person is requested by another Member State, that person's human rights will automatically be guaranteed on his arrival there. There can, however, be a presumption of compliance which is rebuttable only on the clearest possible evidence. Such evidence must be specific; propositions of a general nature, however well supported, will not suffice." up entirely to the progressive line taken by the Ghent KI in the Jauregui Espina case a few years later, this may surely serve as proof of the fact that the Union is no longer placing unlimited trust in the unstained reputation of its members in a framework of European cooperation in criminal matters. Earlier, the Common European Asylum Policy (CEAP)and the stipulations of the Dublin II Convention had also come under fire from the European Court of Human Rights in the case MSS. vs. Belgium and Greece. ${ }^{49}$ A few months later, the Court of Justice had to acknowledge in the context of the similar NS. case ${ }^{50}$ that the trust placed in member states by the CEAP with regard to their fundamental rights compliance was in fact not waterproof.Scholars had already been aware of this and did not spare their - often fierce - criticism of the assumed mutual trust ${ }^{51}$ and the potential harmful consequences vis-à-vis the fundamental

45 With eight (!) judgments confirming breaches of Articles 5 (lawful detention) and 3 (prohibition of torture, inhuman or degrading treatment) ECHR on the 9th of January 2014 and very recently, on the 3rd of February 2015, eight more for breaches of Article 5 ECHR.See: http://hudoc.echr.coe.int/sites/eng-press/pages/search.aspx? $\mathrm{i}=003-4626690-5599572 \#\{\% 22$ itemid\%22:[\%22003-4626690-5599572\%22]\}\&http:// hudoc.echr.coe.int/sites/eng-press/pages/search.aspx?i=003-5004421-6141156.

46 European Court of Human Rights (ECtHR), 16 oktober 2012, Otamendi Egiguren v. Spain.via: http://hudoc.echr.coe.int/sites/eng/pages/search.aspx?i=001-114095.

47 European Court of Justice (ECJ) 18.10.2012, case C-396/11, (Radu) via:http:// curia.europa.eu/juris/document/document.jsf?text=\&docid=132981\&pageIndex=0\&doclang $=E N \&$ mode $=1$ st $\&$ dir $=\& o c c=$ first $\&$ part $=1 \&$ cid $=482327$.

48 Ibid. Conclusion of the Advocate General, para. 41.

49 MSS. v. Belgium E Greece, Application no. 30696/09, Judgment 21 January 2011.

50 European Court of Justice (ECJ) 21.12.2011, case C-411/10 \& C-493/10 (“N.S.").

51 S. Alegre, Mutual trust - Lifting the mask, in: G. De Kerkhove\& A. Weyemberg (Eds.), La confiance mutuelle dans I'espace penal Europeen; Mutual trust in the European criminal 
rights of those involved in procedures of mutual recognition, aimed at repression and prosecution. ${ }^{52}$ Finally, one also needs to point out the role of international (non-governmental) organisations that continuously raise these issues via monitoring and reports. Notwithstanding the non-binding nature of most these organisations' powers and reports, their influence should not be underestimated, given they acquire a binding force $e^{53}$ to a certain degree via the jurisprudence of the European Court of Human Rights. Seeing that such reporting was accepted as decisive in the Jauregui Espina case and the motivation passed the Court of Cassation, it does not seem overly expeditious to state that also the Belgian jurisprudence has warmed up to this European trend.

\section{Consequences and possible solutions for European cooperation in criminal cases}

A good ten years following the traumatic experiences brought about by international and European terror, European cooperation in criminal cases finds itself at a cross roads.${ }^{54} \mathrm{On}$ the one hand, it seems the Union is confirming trust in mutual recognition, decisively taking the flight forward by formally enshrining the principle in the Treaty concerning the Functioning of the European Union (art. 82,1 TFEU). ${ }^{55}$ On the other hand, the gap between the smooth cooperation that exists in theory and the lacklustre implementation and use of the instruments in practice is continuously increasing, and the ease with which member states seem to find their way to the human rights argument, to the detriment of presupposed mutual trust, appears to be steadily increasing. These developments are moreover mutually reinforcing, posing a potential risk for the future of mutual recognition as the crux of European cooperation in criminal cases. The Jauregui Espina case offers a recent and interesting illustration of the fact that the abovementioned tendencies are slowly but steadily undercutting the bastion of the

area, Brussels: Eds. de I'Universite de Bruxelles, 2005, pp. 41-45; H.G. Nilsson, Mutual trust or mutual mistrust? In G. de Kerchove\& A. Weyemberg (Eds.), La confiance mutuelle dans l'espace penal europeen; Mutual trust in the European criminal area, Brussels: Ed. de l'Universite de Bruxelles, 2005, pp. 29-40.

52 M. Anderson, Law enforcement cooperation in the EU and fundamental rights protection, in: Martin, M. (ed), Crime, rights and the EU: the future of police and judicial cooperation, Justice, 2008, pp. 105-108; K. Ambos, Mutual recognition versus procedural guarantees?, in: de Hoyos Sancho, M. (ed), Criminal proceedings in the European Union: essential safeguards, Lex Nova, 2008, pp. 25-38.

53 A recent and relevant example hereof is the case of L.B. v. Belgium of 2 October 2012 where the ECtHR based its judgment concerning the breach of Article 5 ECHR regarding detention conditions for a mentally ill offender (internee) on the explicit reference to a CPT report.See: L.B. c. BELGIQUE, Requête no 22831/08, judgment 02 October 2012.

54 G. Vermeulen $\mathcal{E} W$. De Bondt, First things first: Characterising mutual recognition in criminal matters, in: B. De Ruyver, T. Vander Beken, F. Vander Laenen \& G. Vermeulen (Eds.), EU criminal justice, financial \& economic crime : new perspectives interest-based dispute resolution, Maklu, 2011, pp. 17-38.

55 "Judicial cooperation in criminal matters in the Union shall be based on the principle of mutual recognition of judgments and judicial decisions." And this since the coming into force of the Lisbon Reform Treaty (1 December 2009). 
EAW. While a more critical attitude rooted in a human rights reflex taking the palace of blind trust between member states may seem a positive development, this tendency however gives rise to a number of reflections - which will be outlined in the paragraphs below.

\section{The European reaction. Is the EU blowing hot and cold?}

\section{The Roadmap for procedural rights}

The Union has not sat idly by while the identified issues of failing mutual trust and the proof of poor compliance with human rights obligations by the member states were increasing. In 2000, a first step was taken to place fundamental rights in the limelight within the EU, via the Charter of Fundamental Rights of the European Union. ${ }^{56}$ The fact that it would take until 2009 - the entry into force of the Lisbon Treaty - for the Charter to come into force, however, is an indication of the mainly symbolic value that was held by the instrument in its early stages. Also within the specific context of European cooperation in criminal cases, the European Commission started to respond - by as early as 2003 - to the increasing criticism on mutual recognition and the lack of attention for human rights exercised in the framework of the European arrest warrant via a green paper on procedural rights. ${ }^{57}$ Following the unsuccessful ending of the ambitious proposal that consisted in establishing a framework decision on procedural rights in criminal procedures ${ }^{58}$, it took until 2009 before a new measure saw the light of day with the Roadmap on procedural rights of suspects or accused persons in criminal procedures..$^{59}$

This Roadmap consists of a step-by-step approach that aims to strengthen the protection of procedural rights of suspects and accused persons via a package of - current-

56 Charter of Fundamental Rights of the European Union, OJ C 364/1, via: http:// www.europarl.europa.eu/charter/pdf/text_en.pdf.

57 European Commission, Green Paper on Procedural Safeguards for Suspects and Defendants in Criminal Proceedings throughout the European Union. Brussels: $\operatorname{COM}(2003) 75$ final, 2003. Via: http://eur-lex.europa.eu/LexUriServ/site/en/com/2003/com2003_0075en01.pdf.

58 European Commission, Proposal for a Council Framework Decision on certain procedural rights in criminal proceedings throughout the European Union. COM 328 final, 2004.via: http://eur-lex.europa.eu/LexUriServ/LexUriServ.do?uri=CELEX:

52004PC0328:EN:HTML.The final death knell for this instrument were the highly contested competence of the Union to take - separate from a cross-border dimension - such initiatives and the vagueness of the proposed rights included in the instrument. See: C. Morgan, Where are we now with EU procedural rights? European Human Rights Law Review(4), 2012, pp. 427-432; G. Vermeulen \& L. van Puyenbroeck, Towards minimum procedural guarantees for the defence in criminal proceedings in the EU. International and Comparative Law Quarterly (ICLQ), 60(04), 2011, pp. 1017-1038.

59 Council of the European Union, Resolution of 30 November 2009 on a Roadmap for strengthening procedural rights of suspected or accused persons in criminal proceedings. OJ C 295/1, 2009, via: http://eur-lex.europa.eu/LexUriServ/LexUriServ.do?uri=OJ:C:2009:295: 0001:0003:EN:PDF. 
ly $\operatorname{six}^{60}-$ measures. So far, the first four measures have already been turned into three Directives. ${ }^{61}$ The Roadmap starts by providing an explanation for its main raison d'être. It considers that "Indeed, whilst various measures have been taken at European Union level to guarantee a high level of safety for citizens, there is an equal need to address specific problems that can arise when a person is suspected or accused in criminal proceedings" 62 and that "This calls for specific action on procedural rights, in order to ensure the fairness of the criminal proceedings. Such action, which can comprise legislation as well as other measures, will enhance citizens' confidence that the European Union and its Member States will protect and guarantee their rights." ${ }^{3}$ The aims of the Council are clear, as can also be gathered from the reflections included in the Roadmap itself ${ }^{64}$ : With a view of enhancing mutual trust as well as the mutual recognition based hereupon between member states, it calls for the introduction of minimum standards that subsequently have to be correctly implemented and applied. Notwithstanding the potential of the Roadmap to lift the criminal procedures of member states to a higher level of protection ${ }^{65}$ and thereby to improve the (procedural) rights of persons involved, it can be called into question whether this approach will effectively offer a better solution for tackling the identified threats to cooperation in criminal cases. Since the inception of the Roadmap, a lot of ink has been spilled over the instrument's competence and scope. ${ }^{66}$ Although legal doctrine still formulates the necessary critical questions concerning the EU's competence with regard to the introduction of minimum standards for situations that can (also) be qualified as merely domestic issues on

60 Measure A on translation and interpretation; Measure B on information on rights and information about the charges; Measure $\mathrm{C}$ on legal advice and legal aid; Measure $\mathrm{D}$ on communication with relatives, employers and consular authorities; Measure E on special safeguards for suspected or accused persons who are vulnerable; Measure F Green Paper on pre-trial detention.

61 Measure A was turned in Directive 2010/64/EU of the European Parliament and the Council of 20 October 2010 on the right to interpretation and translation in criminal proceedings. OJ L/280, 26 October 2010; Measure BB in Directive 2012/12/EU of the European Parliament and the Council of 22 May 2012 on the right to information in criminal proceedings. OJ L/ 142, 1 June 2012; Measures C and D where comprised in Directive 2013/48/EU of the European Parliament and the Council of 22 October 2013 on the right of access to a lawyer in criminal proceedings and in European arrest warrant proceedings, and on the right to have a third party informed upon deprivation of liberty and to communicate with third persons and with consular authorities while deprived of liberty. OJ 2013 L 294, 6 November 2013.

62 Ibid. (fn. 59), Consideration (4).

63 Ibid. (fn. 59), Consideration (5).

64 Consideration (8) of the Procedural Roadmap clearly states that Mutual recognition presupposes that the competent authorities of the Member States trust the criminal justice systems of other Member States. For the purpose of enhancing mutual trust within the European Union, it is important that, complementary to the Convention, there exist European Union standards for the protection of procedural rights which are properly implemented and applied in the Member States.

65 Vermeulen, Panopticon 2013, p. 349.

66 The right to information, the presence of a lawyer, etc. as provided for in the Directives are after all also applicable in sheer domestic criminal procedures, so it appears that the Union is stretching its competence. 
the basis of article 82,2. TFEU ${ }^{67}$, it appears that both the Union and its member states tend to run along with this option for the time being. This being the case, the first hurdle - which seemed insurmountable when the framework decision for procedural rights was first suggested - at least appears to have been taken. More important, perhaps, is the precise goal that was set for the Roadmap. In its considerations ${ }^{68}$ the instrument clearly refers to its complementary role vis à vis the ECHR in order to ensure an improved compliance with the Convention and its additional protocols as an essential condition for mutual trust between member states. The fact that such complementary action appears to be necessary on a procedural level in order to guarantee the 'fairness' of procedures, means that the Union once more seems to acknowledge the unsatisfactory nature of the assumed trust. Yet in defence of this view it can be noted that the diversity that exists in terms of application of the ECHR within the different member states, as well as the often insurmountable conditions for a procedure at the Court ${ }^{69}$, often hamper an effective guarantee of individual rights. ${ }^{70} \mathrm{It}$ therefore is to be welcomed that additional measures are taken on an EU level in order to protect procedural rights.

It seems more difficult, however, to offer an explanation as to how the Roadmap can be understood within the framework of a reappraisal of mutual recognition, given the instrument now appears to have severed ties with the cross-border dimension of criminal cases. This is due to the fact that the procedural safeguards that have already been created are (also) applicable in strictly internal matters and moreover fail to elucidate how they will function in the presence of already existing instruments that are based on mutual recognition. Clearly, the Roadmap and the ensuing guidelines do not eye a modification of the existing instruments, let alone the introduction of additional grounds for refusal or margins of appreciation. One could moreover argue that the current Directives are focusing on rather traditional rights to complement a package of tools that already seems sufficiently developed with regard to his matter. ${ }^{71}$ Without aiming to detract from the essential nature of e.g. a right to translation, one could argue that such rights are already sufficiently reflected in the ECHR and its additional proto-

67 Article 82, 2 TFEU clearly states "to the extent necessary to facilitate mutual recognition...in criminal matters having a cross border dimension... may...establish minimum rules". As such, there needs to be a clear trans-boundary dimension and a link with mutual recognition in criminal matters. See: W. De Bondt E G. Vermenlen, The procedural rights debate A bridge too far or still not far enough? Eucrim(4), 2010, pp. 163-167; T. Marguery, European Union fundamental rights and member states action in EU criminal law. Maastricht Journal, 20(2013/2), 2013, pp. 282-301; Morgan, European Human Rights Law Review 2012.

68 Ibid. (fn. 59), Considerations (1) \& (2).

69 By means of example: In its judgment of 22 May 1998 in the case of Hozee v. Netherlands (App. No.21961/93), the ECtHR ruled that, after 18 years of litigation, the reasonable term as included in Article 6 ECHR was not breached. As such, a more than reasonable perseverance and time, money, means and luck are expected of the applicants, not to mention the Court's stringent admissibility threshold.

70 P. Langford, Extradition and fundamental rights: the perspective of the European Court of Human Rights. The International Journal of Human Rights, 13(04), 2009, pp. 512-529.

71 De Bondt E Vermeulen, Eucrim 2010, p. 165; Marguery, Maastricht Journal 2013. 
cols, the Charter of Fundamental Rights of the European Union and the fundamental rights that ensue from member states' constitutional traditions. ${ }^{72}$ Complementing such rights via the Roadmap in order to ensure better compliance - which, as indeed has been established, has its shortcomings - is a good thing, but leaves room for improvement: The complete absence of attention for procedural rights in the (pre-trial) phase of the collection of evidence can be termed a missed opportunity. With the contentieux of both the ECHR and the Court according little attention to this, it follows that a complementary approach in this field would be welcome. With the European Investigation Order in the pipeline, we can moreover point out the current attention given to this matter within the field of mutual recognition. ${ }^{73}$ Clearly, the opportunity to react swiftly to developments and create procedural guarantees in this matter has not (yet) been acted upon.

The ambiguity that exists with regard to the Roadmap's relation with cross-border cooperation and the decision to opt for more traditional procedural rights (for the time being), give rise to the fear that the Roadmap will not be able to strengthen mutual trust and cooperation in the Union. However, in spite of the fact that the Roadmap finds its foundation in treaty law, this does not always appear to be the Union's main goal. Rather than reviewing the package of existing (or future) instruments based on mutual recognition in the light of the increasing number of issues concerning human rights, the EU appears to be striving for a union-wide upgrade of procedural rights outside the framework of any cross-border elements determined by treaty law. An important indication in this regard was already formulated back in 2009, when the procedural Roadmap stated in its consideration (10) that it strives "to strengthen procedural guarantees and the respect of the rule of law in criminal proceedings, no matter where citizens decide to travel, study, work or live in the European Union." Clearly this goes beyond a cross-border context in criminal law and merely repairing trust in (the instruments of) mutual recognition. One can superfluously refer to the impact report that accompanies the proposition concerning the Guideline for procedural guarantees attributed to children in procedures of criminal law, in which the Commission plainly states that the Guideline is (/will be) implemented in disregard of any cross-border connotation. ${ }^{74}$

72 Article 6 CFREU.

73 Vermeulen, Pantopticon 2013.

74 Point 4.5.1, paragraph 2 of the: European Commission, COMMISSION STAFF WORKING DOCUMENT IMPACT ASSESSMENT Accompanying the document Proposal for a directive of the European Parliament and of the Council Proposal for a on procedural safeguards for children suspected or accused in criminal proceedings $/ *$ SWD/2013/0480 final \%/., 2013, p. 31. Via: http://eur-lex.europa.eu/legal-content/en/ALL/?uri=CELEX:52013SC0 480. 
2. Fundamental rights between protection and cooperation? The reluctance of the European Court of Justice

The procedural Roadmap appears to carry the banner of the importance and improvement accorded to fundamental (procedural) rights by the Union. The fact that the Roadmap, in trying to achieve this goal, does not aim (directly) at the instruments for cooperation - and this in spite of its basis in treaty law- begs the question of the relation between an effective protection of fundamental rights on the one hand, and the necessity of effective European cooperation in criminal matters on the other. The most puzzling question undoubtedly resides in situations where member states find themselves confronted with a request (or order) for cooperation by a second member state, and have to address the issue of a potential decline due to a lack of fundamental rights compliance by the issuing member state. These rights can either ensue from a country's own constitution or from the EU Charter and the ECHR. The (complementary) safeguards of the procedural roadmap can now also be added to this list. This type of issue also constituted the base of the KI's judgement in the Jauregui Espina case, where it was decided on the basis of available reports that a surrender in accordance with the European Arrest Warrant was not possible according to the human rights related ground for refusal established in the Belgian "Wet EAB". As mentioned above, such a ground for refusal was introduced as an own-initiative measure by a number of member states which found permission for this in preamble and article 1(3) of the Framework Decision of the EAW.

Such introductions, as mentioned earlier, were only very meagrely appreciated by the European Commission. ${ }^{75}$ Comparing the grounds for refusal that exist in the member states that have provided for one, it becomes apparent that they still come in many different shapes and interpretations. ${ }^{76} \mathrm{~A}$ significant number of member states moreover have not acquired this big stick. As such, there is no common view within the Union as to how and when human rights can give rise to an exception with regard to the use of instruments of mutual recognition. This diversity causes the arrest warrant to operate in a legal limbo ${ }^{77}$ as far as fundamental rights are concerned, given that the framework decision itself only provides for limited grounds for refusal and refrains from explicitly mentioning the human rights exception. It is not just variety that exists in member states, however, that raises a number of questions. This is also the case for the increasing number of tools that exist on fundamental rights: What is the relation of the

75 European Commission, Report from the Commission based on Article 34 of the Council Framework Decision of 13 June 2002 on the European arrest warrant and the surrender procedures between Member States (revised version) $\{\mathrm{SEC}(2006) 79\} / * \mathrm{COM} / 2006 / 0008$ final $\%$ 2006.Via: http://eur-lex.europa.eu/LexUriServ/LexUriServ.do?uri=COM: 2006:0008:FIN:EN:HTML. In this report, the Commission indicated that roughly 2/3rds of the member states used this reasoning to introduce a human rights refusal ground.

76 A. Tinsley, The Reference in case C-396/11 Radu: When does the protection of fundamental rights require non-execution of a European arrest warrant? European Criminal Law Review (EuCLR), 2(3), 2012, pp. 338-352.

77 Ibid. p. 341.

EuCLR Vol. 6, 2/2016 
EU fundamental rights Charter to the ECHR, more specifically regarding the interpretation of the Human Rights Court's doctrine concerning flagrant violations in the context of cooperation in criminal cases? Can a member state refuse collaboration on the basis of a potential violation of the Charter, while there is a possibility that the violation does not meet the threshold of the ECHR, as interpreted by the Court? Where can we situate the additional safeguards of the Roadmap's Directives in this context? These questions tend to create a stern headache for both the person involved as well as the state that finds itself confronted with an arrest warrant. While the former's salvation lies - ad ultimum - beyond the towering threshold established by the European Court of Human Rights and its flagrant violation doctrine, the member state has to turn to the European Court of Justice. This EU institution therefore holds the key to safeguarding the uniformity as well as conformity of European Cooperation in criminal cases in relation to the fundamental rights. ${ }^{78}$

In two recent judgments, the Court found itself confronted with such a question in the wake of an EAW procedure. The aforementioned Radu case and the Melloni case ${ }^{79}$ presented the court with a golden opportunity to dot the i's and cross the t's as far as the difficult relation between the EAW and the fundamental rights were concerned. In the first case, the Court had to pronounce itself on the relation between fundamental rights as included in the EU Charter and the ECHR and a requested European arrest Warrant. Romania, as sought executing state had not included the human rights violation clause as a grounds for refusal and now had reflect upon whether Mr. Radu was in a position to invoke the (flagrant violation of) the human rights included in the Charter and the $\mathrm{ECHR}^{80}$ in order for his surrender to be refused. As mentioned earlier, the Advocate General in this case did not show herself averse to thorough reflections on the relation between mutual recognition on the one hand and respect for fundamental rights on the other ${ }^{81}$, the importance of which cannot be denied on at least a symbolic level. The Court, however, shied away from following Sharpston's engaging advice, limited its vision to one specific observation - in casu Radu not having been heard prior to the issuing of the EAW - and even on that account retreated to the familiar rhetoric on mutual trust between member states. Confronted with a context of European cooperation in criminal cases, the Court even seems to be stepping back from the rather

78 P. Asp, N. Bitzilekis, S. Bogdan, T. Elholm, L. Foffani, D. Frände,..., E F. Zimmerman, A manifesto on European criminal procedure law - European Criminal Policy Initiative. Zeitschrift für International Strafrechtsdogmatik 11, 2013, pp. 430-446.

79 European Court of Justice (ECJ), 20.4.2013, case C 399/11 (Ministerio Fiscal/ Stefano Melloni). Via: http://curia.europa.eu/juris/document/document.jsf;jsessionid=9ea7dof130d5f2bd b1932eb7422eb87fe1f08fa18fdf.e34KaxiLc3eQc40LaxqMbN4Oc34Le0?text=\&docid=13589 4\&pageIndex $=0 \&$ doclang $=E N \&$ mode $=$ req $\&$ dir $=\& o c c=$ first $\&$ part $=1 \& \operatorname{cid}=735679$.

80 Part of the debate was also the question of whether fundamental rights should be considered as primary EU law since the Lisbon Reform Treaty, even if they were not foreseen as such at the time of the conception of the Framework Decision on the European Arrest Warrant.

81 Sharpston even opened the door for a more flexible approach regarding the 'flagrant denial' doctrine of the ECtHR, by stating that potential infringements should not be established 'beyond reasonable doubt'. 
progressive attitude adopted in the NS. case (in the context of the common policy on asylum) ${ }^{82}$ Hopes to the effect that the Court would choose the path of more decisive action in this context over the following years were also met with disappointment.

In the Melloni case, the Court concluded that a member state cannot apply a higher national standard of fundamental rights protection to refuse an issued arrest warrant that complies with the (lower standard of) protection established by the EU Charter. Once again, the Court confirms that any other assessment would work to the detriment of the fundamental principles of mutual trust and the recognition which the framework decision aims to enhance. This would moreover compromise the expediency of the framework decision given the uniformity of the fundamental rights protection, as established in the instrument, would be put up for discussion..$^{83} \mathrm{An}$ important aspect of the Court's reasoning for this refusal was that the EU had already established a harmonisation pathway and that allowing a higher national level of fundamental rights protection would therefore run counter to the aim of the provision to provide a common understanding of that refusal ground (in casu concerning in absentia decisions). ${ }^{84}$ Hence, Janssens rightfully states that in areas where the EU legislator has established (common minimum) definitions at EU level, the member states' margin of action will be smaller in cases where no common definitions exist and that the principle of mutual recognition will be more powerful - with more limited exception to this principle - where approximation is available. ${ }^{85}$ Concurrently with the Melloni case, the Court also ruled the Akerberg Fransson judgment ${ }^{86}$ in which it is stated - although not in the context of cross-border collaboration in criminal cases - that member states are bound to uphold the fundamental rights established in the Charter when their actions fall within the scope of the law of the Union. ${ }^{87}$ It is clear that the Court ensured that both judgements were attuned to one another, on the one hand by guaranteeing that the Charter is valid whenever the law of the Union is applicable, and on the other by considering that same Charter as the ultimate upper limit as far as the human rights

82 It needs mentioning, however, that the Court of Justice would perhaps have been more reluctant, should not the Human Rights Court had settled a similar discussion with "a resounding condemnation" in the case of MSS. v. Belgium \& Greece. See:N. Mole, The complex and evolving relationship between the European Union and the European Convention on Human Rights, European Human Rights Law Review (EHRLR), Issue 4., 2012, p. 366.

83 Ibid. (fn. 79), Consideration 63.

84 H. Labayle, Mandatd'arrêteuropéen et degré de protection des droits fondamentaux, quand la confiance se fait aveugle. Groupe de Recherche - EspaceLibertéSécurité Justice, 2013. http://www.gdr-elsj.eu/2013/03/03/cooperation-judiciaire-penale/mandat-darret-europeenet-degre-de-protection-des-droits-fondamentaux-quand-la-confiance-se-fait-aveugle/print/; $R$. van der Hulle E $R$. van der Hulle, De arresten Akerberg Fransson en Melloni gerelativeerd, Tijdschrift voor Europees en economisch recht (SEW), J, March, 2014, pp. 102-116; I. Armada, The European Investigation Order and the Lack of European Standards for Gathering Evidence. Is a Fundamental Rights-Based Refusal the Solution? New Journal of European Criminal Law, 6(1), 2015, pp. 8-31.

85 C. Janssens, The Principle of Mutual Recognition in EU Law, Oxford Studies in European Law, OUP Oxford, 2013, p. 204.

86 European Court of Justice, 26.2.2013, Case C-617/10 (Aklagaren/ Hans Akerberg Fransson)

$87 R$. van der Hulle E R. van der Hulle, SEW 2014. 
guarantees are concerned which needs to be respected by member states, particularly when they are confronted with an issued measure within the field of European cooperation in criminal cases. Lastly, in its Opinion on the accession of the EU to the ECHR, the Court indicated that the accession to the ECHR would be contrarious to the principle of mutual trust as it would potentially open the gates for states to check the fundamental rights situation in the member state that has demanded its cooperation in the AFSJ. ${ }^{88}$

This analysis demonstrates the reluctance of the Court of Justice to express itself clearly and unambiguously on the relation between fundamental rights, trust between states, and mutual recognition in criminal cases. Yet, this is exactly where the shoe doesn't fit. The differences that exist between member states with regard to the inclusion, interpretation and implementation of a grounds for refusal based on a possible violation of human rights within the procedures of the European arrest warrant beg a clear analysis from the Court. In the Radu case, the Court chose to hide behind the doctrine of mutual trust rather than pronounce itself on the existing thresholds - considered too high by the Advocate General - to successfully refuse an arrest warrant. Yet, as confirmed by the Advocate General in the Lopes Da Silva Jorge case ${ }^{89}$, it would be rather absurd to assume that member states should accept the possibility of human rights violations for the sake of ensuring a smooth collaboration, as long as said violations are not spilling over the thresholds established in the ECHR and the Charter. The complex relation between the several fundamental rights of various origins is also deserving of a uniform approach, in particular in a time when the safeguards of the procedural roadmap are increasingly gaining in prominence. Their role and place needs clarification, lest we end up in a situation in which member states risk to be held liable by the Court of Justice for failing to comply with the obligations that arise from the Roadmap's Directives, while they would effortlessly pass the test of the Charter within a framework of cross border cooperation in criminal matters.

On $24^{\text {th }}$ of July, 2015, the Hanseatisches Oberlandesgericht in Bremen, Germany, requested in a preliminary ruling to the Court of Justice in the Aranyosi case ${ }^{90}$-which

88 European Court of Justice (ECJ) 18.12.2014, Opinion 2/13. See especially Para. 191: "That principle (mutual trust) requires, particularly with regard to the area of freedom, security and justice, each of those States, save in exceptional circumstances, to consider all the other Member States to be complying with EU law and particularly with the fundamental rights recognised by EU law." And Para. 194 "In so far as the ECHR would, in requiring the EU and the Member States to be considered Contracting Parties not only in their relations with Contracting Parties which are not Member States of the EU but also in their relations with each other, including where such relations are governed by EU law, require a Member State to check that another Member State has observed fundamental rights, even though EU law imposes an obligation of mutual trust between those Member States, accession is liable to upset the underlying balance of the EU and undermine the autonomy of EU law."

89 European Court of Justice (ECJ) 5.9.2012, Case C-42/11 (courd'appeld'Amiens /João Pedro Lopes Da Silva Jorge).See also: Tinsley, EuCLR 2012, pp. 347-348.

90 European Court of Justice (ECJ) 24.7.2015, case C-404/15 (Generalstaatsanwaltschaft Bremen/ PálAranyosi). Via:http://curia.europa.eu/juris/document/document.jsf?text=\&docid $=167520 \&$ pageIndex $=0 \&$ doclang $=E N \&$ mode $=1$ st $\&$ dir $=\& o c c=$ first $\&$ part $=1 \& \mathrm{cid}=869267$ 
was later joined with the Căldăraru ${ }^{91}$ case - whether "Article 1(3) of the Council Framework Decision on the European arrest warrant is to be interpreted as meaning that extradition for the purposes of prosecution is impermissible where there are strong indications that detention conditions in the issuing Member State infringe the fundamental rights of the person concerned and the fundamental legal principles as enshrined in Article 6 of the Treaty on European Union, or is it to be interpreted as meaning that, in such circumstances, the executing Member State can or must make the decision on the permissibility of extradition conditional upon an assurance that detention conditions are compliant? To that end, can or must the executing Member State lay down specific minimum requirements applicable to the detention conditions in respect of which an assurance is sought?" With such a clearly structured demand for clarification/interpretation of the FD EAW's stance on fundamental rights in relation to detention conditions, and with the Radu and Melloni cases behind us, the Court's answer was eagerly awaited. Very recently, on $3^{\text {rd }}$ March, 2016, Advocate General Bot presented his Opinion on the joint cases. ${ }^{92}$ Following a rather extensive exposition (including reference to the ECJ's N.s. case), the Advocate General concluded that Article 1(3) of the FD EAW must be interpreted in such a way that it does not constitute a motive to refuse cooperation and execution of a European Arrest Warrant, based on the risk of a violation of fundamental rights in the issuing member state. It is solely up to the judicial authorities of the issuing state to assess the proportionality and necessity of issuing a European Arrest Warrant. ${ }^{93}$ The complex relationship between the fundamental rights and mutual recognition was deserving of a uniform approach - as indicated above - and their role and place in want of clarification. With this opinion by the Advocate General, undoubtedly a crisp and clear answer hereto is provided, but its content may be assessed as "deeply troubling". ${ }^{94}$ This line of reasoning fully accords a higher legal status to the principle of mutual recognition than to (the protection of) the fundamental rights of the individual involved in EAW procedures. Moreover, the deci-

91 European Court of Justice (ECJ) 9.12.2015, Case C-659/15 PPU (HanseatischesOberlandesgericht/ Căldăraru).

92 Y. Bot, Conclusions de l'AvocatGénéral, Affaires C-404/15 et C-659/15 PPU, présentées le 3 mars 2016. Available via (French only):http://eur-lex.europa.eu/legal-content/FR/TXT/ HTML/?uri=CELEX:62015CC0404\&qid=1458121305625\&from=EN.

93 Bot, 2016 (fn. 93), para 183 et sequitur (literally): “L'article 1er, paragraphe 3, de la décisioncadre 2002/584/JAI du Conseil, du 13 juin 2002, relative au mandatd'arrêteuropéen et aux procédures de remise entre Étatsmembres, tellequemodifiéepar la décision-cadre 2009/299/JAI du Conseil, du 26 février 2009, doitêtreinterprétéencesensqu'il ne constitue pas un motif de non-exécution du mandatd'arrêteuropéenémis aux fins de l'exercice de poursuitespénalesou de l'exécutiond'unepeineoud'unemesure privatives de liberté, fondésur le risqued'une violation, dansl'Étatmembred'émission, des droits fondamentaux de la personne remise. Il appartient aux autoritésjudiciairesd'émission de procéder à un contrôle de proportionnalitéafind'ajuster la nécessitéd'émettre un mandatd'arrêteuropéen au regard de la nature de l'infraction et des modalitésconcrètesd'exécution de la peine."

94 See Fair Trials International and Antigone's Opinion Letter and request to the Commissioner for Justice, Consumers and Gender Equality Jourová here: http://statewatch.org/news/ 2016/mar/eu-european-arrest-warrant-ecj-bot-opinion-letter.pdf.

EuCLR Vol. 6, 2/2016 
sion to issue an EAW and the assessment of the proportionality and justness hereof remains the sole prerogative of the issuing state. For what concerns the analysis above, this - at least - would stultify the Belgian Court of Cassation's reasoning in the Jauregui Espina case. Inherently non-legally binding, it remains to be seen how the Court will assess the AG's conclusion and ultimately decide on its opinion.

\section{The missing link? Collaboration between member states and third countries that are party to the ECHR}

The preceding headings already pointed out the risks inherent in the legal twilight zone that is the EAW's turf. The diversity that exists between member states in terms of interpretation and implementation of the human rights argument as an exception for European cooperation, as well as the increasing complexity that has been created by a multi-track approach that has failed to sufficiently elucidate the necessary coherence between fundamental rights and additional safeguards, result in a reduced (procedural) position for the individual involved. At the same time, the member states also remain in the dark on how to find a legitimate balance between smooth collaboration on the one hand and the insurance that fundamental rights are guaranteed, on the other. The Union's reaction to the above illustrated tendency towards decreasing mutual trust consisted in producing the procedural Roadmap. The lack of a consistent and elucidating analysis of the European Court of Justice as to how European cooperation in criminal cases should relate to fundamental rights, as well as the missing link with this cooperation in the approach of the Roadmap, mean that the question regarding the EU's (and the Roadmap's) aim and purpose remains unanswered. Specifically in terms of whether indeed an efficient and just cooperation was envisioned. ${ }^{95}$

The significant gap that exists in the approach of the Union with regard to cooperation in criminal cases and fundamental rights between EU member states on the one side, and third states that are members of the Council of Europe $(\mathrm{CoE})$ on the other, constitutes an indication to the contrary - or at least to the effect that such high-brow concerns stop at the European Union's borders. After all, when the essence of mutual recognition is called to mind, the common membership of the ECHR serves as the most important indication for the states' joint commitment to fundamental rights. When this became untenable due to a long series of judgements issued by the Court of

95 Vermeulen seems to deny this last assertion and states that the procedural roadmap, in consideration (10), already showed that "efforts should be deployed to strengthen procedural guarantees and the respect of the rule of law in criminal proceedings, no matter where citizens decide to travel, study, work or live in the European Union" which clearly indicates that an improved Union in terms of procedural rights is the goal, rather than improving cooperation. This goal would be contrarious to the historical aversion of the member states visà-vis harmonization on an EU level of their criminal systems. See: G. Vermeulen, Flaws and contradictions in the mutual trust and recognition discourse: casting a shadow on the legitimacy of EU criminal policy making \& judicial cooperation in criminal matters? in: Persak $\mathrm{N}$, editor. Legitimacy and trust in criminal law policy and justice. Ashgate; 2014. pp. 153-75. 
Human Rights, the EU changed its tack and launched the Roadmap Guidelines. The latter's prior concern, however, seems directed first and foremost towards harmonising national minimum standards, rather than towards guaranteeing fundamental rights within a cross-border context. When one or multiple member states are confronted with requests for cooperation with a non-EU state that is member of the Council of Europe (and therefore party to the ECHR) in criminal cases, a two-track policy emerges. Within the EU - eg. when a request from the CoE member also necessitates cooperation between the EU member states - one has to operate within a complex situation that includes multiple sources for protection and member states need to ensure that minimum standards aimed for by the Roadmap are met. Once the outer border is crossed, however, these objections would then cease to exist, and cooperation can be resumed without any problem whatsoever. This at least begs the question of coherence, given that in both cases it concerns a member of the ECHR - the self-proclaimed foundation for mutual trust. Two interpretations can be put forward with regard to the notion that trust needs to be shored up with additional procedural guarantees when EU member states are concerned, while this would no longer be necessary or possible when it concerns an EU member state and a requesting state that is a member of the Council of Europe: on the one hand, that the trust between EU member states and third states with regard to justice and the followed and to be followed procedures is such that additional guarantees are unnecessary in this context ${ }^{96}$, and on the other hand that the latter issue no longer appears to be of concern to the Union once its borders are crossed. Both interpretations are detrimental to the strengthening of trust and counterproductive for European cooperation in criminal cases.

\section{Conclusion}

The identified European trend and the concrete example of the Jauregui Espina case offer sufficient food for thought when it comes to the future for the European Union in the context of cooperation in criminal cases. Although it is far from the only case in which an arrest warrant was met with refusal on the basis of a possible violation of human rights, the Jauregui Espina case offers an interesting point of departure because of the confrontation with precedents and the evolution that has taken place in points of view since then. In addition, its terror-related nature (the momentum created by terrorism is still considered the breeding ground for the - initial - instruments of mutual recognition) is interesting when seen against the background of the tendency towards increasing insight into the limits and limitations of mutual recognition in criminal cases. With the strong statements made by the KI of Ghent and the confirmation by Belgium's highest ranking court, the case constitutes the umpteenth proof of the fact that the Union urgently needs to reflect upon its current and future arsenal of instruments

96 Which would imply that the compliance with fundamental rights within a wider CoE context would be unproblematic, an assumption that is profoundly contradicted by scholars and the Human Rights Court's case law.

EuCLR Vol. 6, 2/2016 
based on mutual trust and the relation with fundamental rights. Now that the principle has been formally enshrined through the Lisbon Treaty, the EU - not for the first time - is trying to fend off criticism with an ambitious Roadmap. The (re)appraisal and strengthening of procedural rights through the introduction of minimum standards however raises questions with regard to the legitimacy and competence of the Union to do this. Moreover, significant doubts can be entertained over the aim of strengthening mutual recognition on this basis, given that the connection with mutual recognition seems out of sight. Notwithstanding the fact that the Directives already created constitute a potential improvement for the position of the individual in a criminal procedure, it can be suggested that the EU gets it wrong by introducing additions where these are not really necessary, while the issue of much-needed attention for other (procedural) aspect in criminal cases has been left unaddressed. In what way fundamental rights should be expressed within European cooperation in criminal cases, is a question that for the time being remains unanswered by the EU Court of Justice. The fact that such clarification is necessary, clearly emerges from the problems referred to in this article. Member states currently have to operate in a legal twilight zone. This is not conducive consistency, places diversity and arbitrariness in the driver seat, and potentially exposes individuals involved in such procedures to situations that are detrimental to fundamental rights. 